University of Nebraska - Lincoln

DigitalCommons@University of Nebraska - Lincoln

USDA National Wildlife Research Center - Staff Publications
U.S. Department of Agriculture: Animal and Plant Health Inspection Service

2-26-2002

\title{
Effect of Roost Harassment on Cormorant Movements and Roosting in the Delta Region of Mississippi
}

\author{
Mark E. Tobin \\ U.S. Department of Agriculture, Animal and Plant Health Inspection Service, Wildlife Services \\ D. Tommy King \\ USDA/APHIS/WS National Wildlife Research Center, tommy.king@aphis.usda.gov \\ Brian S. Dorr \\ U.S. Department of Agriculture, Animal and Plant Health Inspection Service, Wildlife Services, \\ brian.s.dorr@aphis.usda.gov \\ Scott J. Werner \\ USDA-APHIS-Wildlife Services, scott.j.werner@aphis.usda.gov \\ David S. Reinhold \\ U.S. Department of Agriculture, Animal and Plant Health Inspection Service, Wildlife Services
}

Follow this and additional works at: https://digitalcommons.unl.edu/icwdm_usdanwrc

Part of the Environmental Sciences Commons

Tobin, Mark E.; King, D. Tommy; Dorr, Brian S.; Werner, Scott J.; and Reinhold, David S., "Effect of Roost Harassment on Cormorant Movements and Roosting in the Delta Region of Mississippi" (2002). USDA National Wildlife Research Center - Staff Publications. 501.

https://digitalcommons.unl.edu/icwdm_usdanwrc/501

This Article is brought to you for free and open access by the U.S. Department of Agriculture: Animal and Plant Health Inspection Service at DigitalCommons@University of Nebraska - Lincoln. It has been accepted for inclusion in USDA National Wildlife Research Center - Staff Publications by an authorized administrator of DigitalCommons@University of Nebraska - Lincoln. 


\title{
Effect of Roost Harassment on Cormorant Movements and Roosting in the Delta Region of Mississippi
}

\author{
MARK E. TOBIN ${ }^{1,2}$, D. TOMMY KING ${ }^{1}$, BRIAN S. DORR ${ }^{1}$, \\ SCOTT J. WERNER ${ }^{1,3}$ AND DAVID S. REINHOLD ${ }^{1,4}$ \\ ${ }^{1}$ U.S. Department of Agriculture, Animal and Plant Health Inspection Service, Wildlife Services \\ National Wildlife Research Center, Mississippi Research Station \\ P.O. Drawer 6099, Mississippi State University, MS 39762
}

${ }^{2}$ Present Address: U.S. Dept. of Agriculture, Animal and Plant Health Inspection Service, Wildlife Services National Wildlife Research Center, 4101 LaPorte Avenue, Fort Collins, CO 80521

${ }^{3}$ Internet: swerner@netdoor.com

${ }^{4}$ Present Address: U.S. Dept. of Agriculture, Animal and Plant Health Inspection Service, Wildlife Services 6213 East Angus Drive, Raleigh, NC 27617

\begin{abstract}
Double-crested Cormorant (Phalacrocorax auritus) predation on Channel Catfish (Ictalurus punctatus) at commercial farms has been estimated to cost the Mississippi aquaculture industry approximately $\$ 5$ million annually to replace consumed fingerlings. In 1997, catfish producers assumed responsibility for the dispersal of cormorants in night roosts in the eastern (interior) delta region of Mississippi, where catfish farms are concentrated. We documented movements of 50 cormorants marked with radio transmitters in the delta region from January through March 1997. We obtained 161 post-capture day locations and 176 post-capture night roost locations. Cormorants that were harassed at their night roost flew farther to their next day's location than birds that were not harassed the previous night. Of the cormorants for which we had more than one night roost location, only $11 \%$ of cormorants that were harassed returned to the same roost within 48 hours, compared with an $81 \%$ return of cormorants to a previously un-harassed night roost. Moreover, cormorants in the eastern portion of the delta (where all harassment was conducted) changed night roosts more frequently than cormorants in the western (non-harassed) delta. Since cormorants in our study foraged relatively close to their night roosts and only $11 \%$ of the birds that we observed roosting in the western delta traveled to the eastern delta to forage the following day, coordinated and intensive dispersal of cormorants from the interior delta may, temporarily, limit cormorant impacts to Mississippi aquaculture. Received 10 July 2001, accepted 17 September 2001.
\end{abstract}

Key words.-Aquaculture, catfish, Double-crested Cormorant, Ictalurus punctatus, Phalacrocorax auritus, radio-telemetry, roost dispersal, roost harassment.

Waterbirds 25(1): 44-51, 2002

The abundance of Double-crested Cormorants (Phalacrocorax auritus) has increased dramatically over much of North America during the past two decades (Buckley and Buckley 1984; Hatch 1984, 1995; Krohn et al. 1995; Weseloh et al. 1995). A conservative estimate of the present abundance of cormorants in the United States and Canada is over one million birds, including breeding and immature individuals, and may be closer to two million (Hatch and Weseloh 1999; Tyson et al. 1999). Although the overall rate of growth of the United States and Canadian population slowed during the early 1990s (Tyson et al. 1999), significant increases continue to occur in some regions. In the Great Lakes region, approximately 200 nesting pairs were observed in 1968 and 1973 (Lud- wig 1984). Approximately 38,000 (Weseloh et al. 1995) and 93,000 nests (Tyson et al. 1999) were counted in the Great Lakes region in 1991 and 1997, respectively. Approximately 115,000 cormorant nests were found during the 2000 breeding season (D. V. C. Weseloh, unpubl. data).

An increase in cormorants wintering in the southeastern United States has coincided with a dramatic increase in commercial production of Channel Catfish (Ictalurus punctatus) in the delta region of Mississippi (hereafter, the delta) (Glahn and Stickley 1995; Glahn et al. 1999, 2000; Mott and Brunson 1997). National production of farmraised catfish expanded from 2.7 million $\mathrm{kg}$ in 1970 to 238.1 million $\mathrm{kg}$ in 1997 (Catfish Institute 1998). The number of cormorants 
wintering in the delta has increased nearly 225 percent since the early 1990s, and over 60,000 cormorants have occupied the delta each winter since 1997-98 (Glahn et al. 2000). Several colonies have also become established in portions of the traditional wintering range in Mississippi and Arkansas (Reinhold et al. 1998).

Given the coincidental increase of cormorant abundance and catfish production in the delta since the mid-1980s, conflicts and economic impacts associated with cormorant predation at catfish farms have emerged. Glahn and Brugger (1995) considered the energetic requirements of cormorants, their relative abundance during the winters of 1989-90 and 1990-91, and the state of the aquaculture industry in the early 1990s (i.e., area and production) to predict the economic impact of cormorants on catfish aquaculture. These authors estimated that the cost of replacing the 18-20 million catfish fingerlings consumed by cormorants each year would be approximately U.S. \$2 million. Glahn et al. (2000) estimated that this replacement cost is now approximately $\$ 5$ million based on the 1997-99 abundance of cormorants wintering in the delta. Glahn et al. (in press) estimated the value of catfish at harvest to be approximately $500 \%$ more than the replacement cost of fingerlings consumed by cormorants. These authors suggested that the ultimate economic loss to catfish farmers (via cormorant predation) may approach $\$ 25$ million.

Several methods have been employed to reduce cormorant predation at catfish farms (Mott and Boyd 1995; Reinhold and Sloan 1999). Many producers assign workers specifically to patrol their farms throughout winter, and harass or kill cormorants foraging on catfish ponds (Mott and Boyd 1995). Aquaculture producers in nine southeastern states reported shooting 7,756 cormorants under Federal depredation permits in 1995, with no apparent effect on either continental or regional cormorant abundance (Belant et al. 2000). In 1998, the U.S. Fish and Wildlife Service issued a Standing Depredation Order (63 FR 10550) that enables aquaculture producers in the southern Unit- ed States and Minnesota to shoot, without a Federal permit, any cormorants that were causing, or were about to cause, damage on their farms.

Some producers also dispersed cormorants from night roosts near their farms. Teams of people fire exploding and whistling pyrotechnics at birds in roosts and at birds flying into the roosts in the evening. Several nights of such harassment usually cause cormorants to abandon roosts (Hess 1994; King 1996; Mott et al. 1992, 1998), and over $70 \%$ reduction in cormorant predation on catfish farms after cormorants were dispersed from nearby roosts has been reported (Mott et al. 1998).

An important objective of the roost harassment program in the delta was to disperse cormorants out of the eastern delta, where catfish farms are concentrated, to roosts along the Mississippi River and adjacent oxbow lakes in the western delta (Glahn et al. 2000). Glahn et al. (1995) analyzed the stomach-esophageal contents of cormorants collected in the delta and found that catfish comprised $77 \%$ of the diet of cormorants captured in the eastern delta but only $20 \%$ of the diet of cormorants captured in the western delta, where Gizzard Shad (Dorosoma cepedianum) made up the bulk of the diet $(75 \%)$. These findings indicate that cormorants in the eastern delta foraged mainly on catfish farms, while those in the western delta foraged mainly in the Mississippi River and adjacent oxbow lakes. Thus, movement of cormorants following roost harassment in the delta may affect subsequent cormorant impacts on catfish production.

King et al. (1995) used radio telemetry to determine the average distances traveled by 18 cormorants from a night roost to their first forage site $(15.7 \mathrm{~km})$, from forage sites to day roosts $(2.6 \mathrm{~km})$, and from one forage site to a subsequent forage site $(5.6 \mathrm{~km})$ in the delta during the winters of 1990-91 and 1991-92. King (1996) also used radio telemetry to study the night roost movements of cormorants in the delta from January to April 1993. King (1996) observed no difference in the greatest distance moved between night roosts for cormorants that were known 
to directly experience roost dispersal $(\mathrm{N}=4)$ compared with those that were not directly observed in harassed roosts during dispersal $(\mathrm{N}=21)$.

The objectives of the present study were to determine the effects of roost harassment on subsequent cormorant movements. We were specifically interested in the effects of roost harassment in the eastern (interior) delta on (1) the distance traveled by cormorants following dispersal in 25 night roosts and (2) the relative fidelity exhibited by cormorants in harassed and undisturbed roosts. The foraging behavior and movements of male and female shags and cormorants have been observed to differ (Casaux et al. 2001; Wtanuki et al. 1996), thus we also analyzed differences in male and female cormorant movements during the winter of 1996-97.

\section{METHODS}

We used methods described by King et al. (1994) to capture 50 cormorants at six roost sites during 15 January-10 March 1997. Sexes were determined via morphological measurements (Glahn and McCoy 1995). Captures were spread over an extended period because inclement weather and moon phase limited when we could capture the birds (King et al. 1994). We attached a $25 \mathrm{~g}$ (1-2\% of body weight), backpack-mounted radiotransmitter (166.006-166.990 MHz, ATS, Inc.®, Isanti, MN) to each bird (Dunstan 1972) and released it within two hours of capture. We began tracking birds two weeks after we captured the first bird.

Two observers with vehicle-mounted, dual three-element yagi antennae and R4000 receivers (ATS, Inc. $\left.{ }^{\circledR}\right)$ monitored the presence of cormorants at known night roost locations (Aderman and Hill 1995; King et al. 1995) along two transects between sunset and sunrise three nights/week. One transect extended $170 \mathrm{~km}$ along the east side of the Mississippi River from Lake Beulah to Vicksburg, Mississippi. In March, as cormorants prepared to migrate north, we extended the transect $130 \mathrm{~km}$ farther north to Tunica, Mississippi. The other transect meandered about $250 \mathrm{~km}$ through the heart of the catfish-growing region from Highway 8 north of Greenwood to south of Yazoo City, Mississippi. We recorded the roost location, date, time, and transmitter frequency of all detected signals.

To determine cormorant daytime locations, we flew once weekly over the southern two-thirds of the delta, south of a line extending from Cleveland, Mississippi to Grenada, Mississippi. In March, we extended the flights to include the northern portion of the delta. We made each daytime aerial telemetry flight between two nights when we monitored roosts from the ground. Flights commenced at about $09.00 \mathrm{~h}$, proceeded in a grid pattern over the study area, and concluded by $16.00 \mathrm{~h}$. We flew in a Cessna 172 fitted with FAA-certified dual three-element yagi antennae mounted on the wing struts. Latitudinal and longitudinal coordinates of birds were determined by either a ground-based long-range navigational system or global positioning system. We recorded the frequency, date, time, and location of all birds detected.

We used a two-tier approach to analyze the data. We compared movements of cormorants known to be at specific roost sites 24 hours prior to being harassed with those of cormorants at non-harassed sites. We also compared movements of cormorants in the eastern delta, where all harassment was conducted, with those of cormorants in the western delta. We allocated all roosts that were less than $90^{\circ} 50^{\prime} \mathrm{W}$ longitude and greater than $32^{\circ} 43^{\prime} \mathrm{N}$ latitude as being in the eastern portion of the delta (Fig. 1). Due to the low number of locations for individual cormorants (typically < five locations per bird), our analyses were conducted on observed locations, rather than individual birds (i.e., the experimental unit was telemetry locations among all birds). SAS statistical software was used to calculate averages, standard errors (reported measure of variance), and median values (SAS Institute, Inc. 1989a, b). Wilcoxon's signed rank test was used to compare groups with regard to distanc-

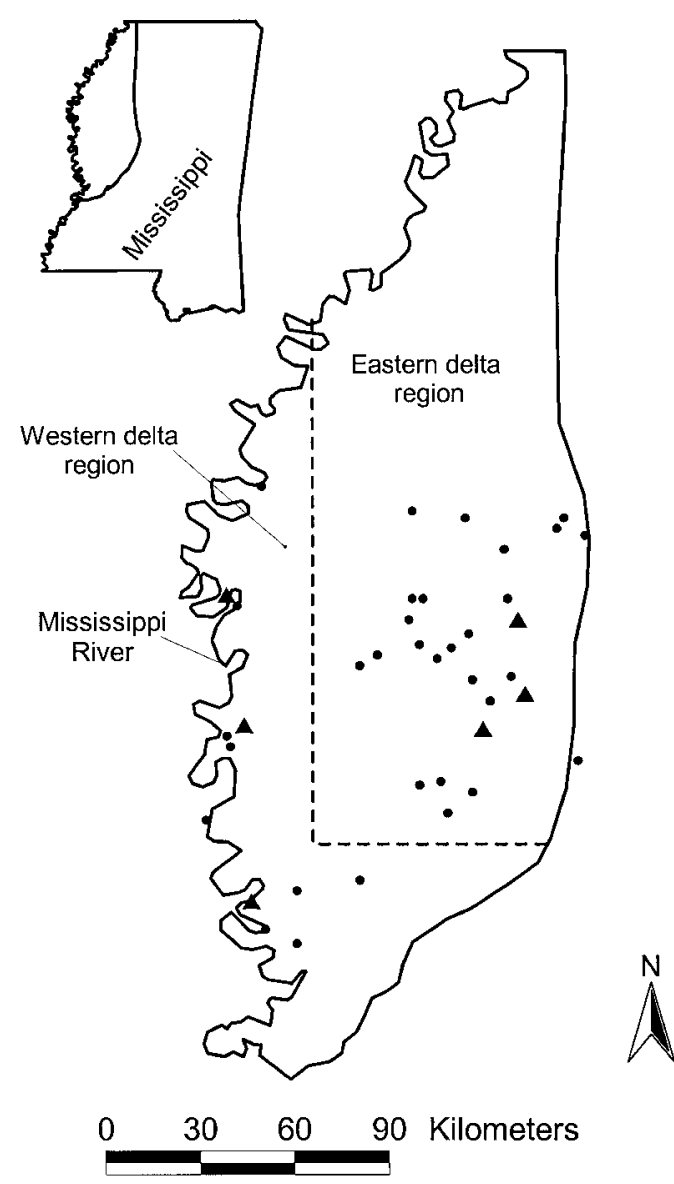

Figure 1. Capture locations (triangles) and 39 night roosts (circles) used by Double-crested Cormorants in the eastern and western delta region (demarcated by dotted lines) of Mississippi. Most Mississippi catfish farms are located in the eastern (interior) portion of the delta. 
es traveled, and chi-square tests using Yates' continuity correction were used to compare classification data (SAS Institute, Inc. 1989a, b).

\section{STUDY AREA}

We conducted the study in the delta region of Mississippi, an area that encompasses $16,000 \mathrm{~km}^{2}$ of alluvial flood plain, most of which has been drained for intensive cultivation of cotton, soybean, and catfish. About $10 \%$ of the original wetlands remain as oxbow lakes, bayous, and Bald Cypress (Taxodium distichum)-Tupelo Gum (Nyssa sylvatica) swamps distributed throughout the delta, especially along the Mississippi River. Catfish farms encompass over 40,000 ha, mostly in the eastern portion of the delta. Cormorants in the delta congregate at night in roosts of up to 24,000 birds in Bald Cypress-Tupelo Gum swamps (Aderman and Hill 1995; Glahn et al. 1996; King et al. 1995; Mott et al. 1992, 1998).

\section{RESULTS}

We located 40 of the 50 birds fitted with radio-transmitters at least once during the eleven weeks that we monitored their movements (Table 1). We tracked each of these 40 birds for a mean of $30.2 \pm 3.06$ days (Range: 1-72). The locations of six birds never moved from their respective capture roosts. We assumed that these birds either died or lost their transmitters, and they were excluded from analyses. Signals from the remaining four birds were never detected.

We detected 161 post-capture day locations and 176 post-capture night roost locations. Overall, we obtained locations for 18$69 \%$ of the birds tracked each week (Table $1)$. We located more birds from the air (46$64 \%)$ than from the ground (18-48\%) during weeks 6-11 (Table 1).

During night monitoring, we determined a mean of $5.5 \pm 0.62$ locations for each of 32 cormorants. These birds roosted in 24 different locations, averaging $2.3 \pm 0.28$ night roosts per bird. Twelve cormorants $(38 \%)$ were detected at only one night roost site, seven (22\%) were detected at two roost sites, seven $(22 \%)$ were detected at three roost sites, five $(16 \%)$ were detected at four roost sites, and one $(3 \%)$ was detected at six night roosts. During daylight hours, we detected a mean of $4.1 \pm 0.39$ locations (Range: 1-9) for each of 39 cormorants. We recorded day locations for 15 birds exclusively in the eastern delta, for eleven birds exclusively in the western delta, with 13 birds located in both areas.

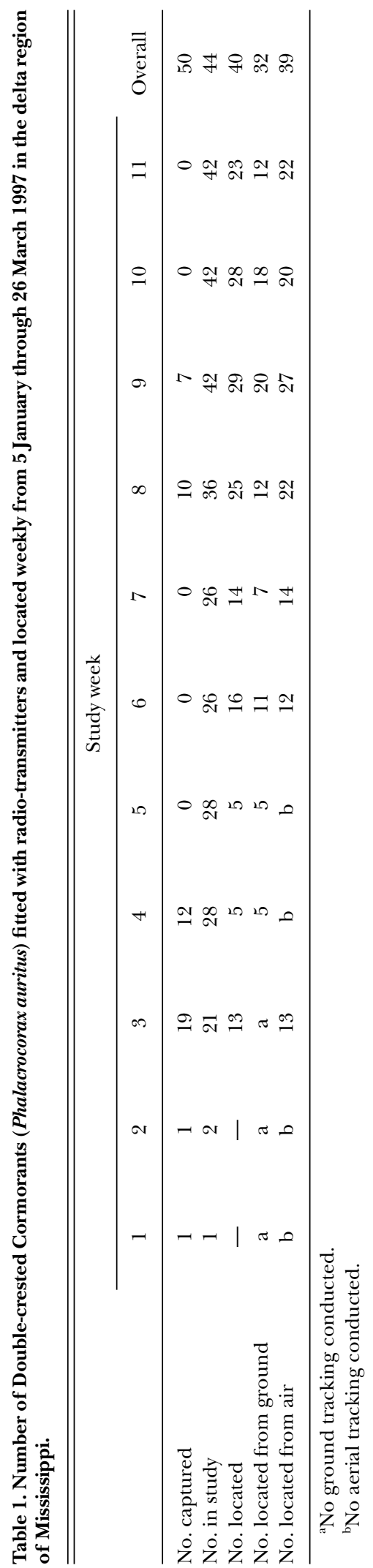


The median distance from each bird's night roost to its subsequent day location (Table 2) was $26.3 \mathrm{~km}$ for females $(\mathrm{N}=20)$ and $22.1 \mathrm{~km}$ for males $(\mathrm{N}=104)(\mathrm{Z}=1.97, \mathrm{P}$ $<0.05)$. Birds that roosted in the western delta $(\mathrm{N}=71)$ moved a median distance of 21.9 $\mathrm{km}$ to their next-day location, compared with $23.8 \mathrm{~km}$ for birds that roosted in the eastern delta $(\mathrm{N}=53)(\mathrm{Z}=0.57$, n.s. $)$.

Birds harassed at their night roosts flew farther $(\mathrm{Z}=2.50, \mathrm{P}<0.02)$ to their next day's location (median distance $=30.6 \mathrm{~km}, \mathrm{~N}=19$, Range: 0-95.5) than did those that were not harassed (median distance $=22.2 \mathrm{~km}, \mathrm{~N}=54$, Range: 0-57.1; Table 2). Of cormorants for which we had more than one night location within $48 \mathrm{~h}$, the distance between successive night locations was not significantly greater $(\mathrm{Z}=1.54$, n.s. $)$ for birds that were harassed (median distance $=17.8 \mathrm{~km}, \mathrm{~N}=8$, Range: 041.4) than for birds that were not harassed (median distance $=3.2 \mathrm{~km}, \mathrm{~N}=76$, Range: 0 57.1; Table 2).

The roost dispersal program entailed harassing birds at 26 roosts in the eastern delta from 29 January through 28 March 1997. Harassment at most roosts was concentrated during 24-28 March 1997, and only two night roosts were harassed more than twice before 24 March. Catfish producers and USDA Wildlife Services biologists visited each roost to harass birds an average of $4.6 \pm 0.30$ times (Range = 1-9), over one- to three-night sessions. Each harassment session consisted of an average of $3.1 \pm 0.30$ consecutive nights $($ Range $=1-4$ ).
Of birds for which we had more than one night roost location, only $11 \%$ of those that were known to have been harassed returned to the same roost within 48 hours, while $81 \%$ of birds that were known not to have been harassed returned to the same roost within 48 hours $\left(\chi_{1}^{2}=20.5, \mathrm{P}<0.01, \mathrm{~N}=88\right)$. Birds in the eastern portion of the delta, where all harassment activities were conducted, changed roosts more frequently than did birds in the western portion of the delta (Fig. 2). Of birds for which we had more than one location within $48 \mathrm{~h}$, only $66 \%$ from the eastern delta returned to the same roost within $24 \mathrm{~h}$, compared with $91 \%$ of birds from the western delta $\left(\chi_{1}^{2}=4.9, \mathrm{P}<0.03, \mathrm{~N}=68\right)$. The same trend held over two nights $\left(\chi_{1}^{2}=9.8\right.$, $\mathrm{P}<0.01, \mathrm{~N}=22)$, and $\geq$ six nights $\left(\chi_{1}^{2}=14.0\right.$, $\mathrm{P}<0.01, \mathrm{~N}=79$ ). There was not a significant difference for the time period three to five nights $\left(\chi_{1}^{2}=3.0\right.$, n.s., $\left.\mathrm{N}=19\right)$.

\section{DISCUSSION}

\section{Cormorant Movements}

Cormorants move extensively in the lower Mississippi valley during winter months (October through March). King (1996) located three radio-telemetered cormorants on the Mississippi and Alabama coast, approximately $350 \mathrm{~km}$ from where he attached radiotransmitters, 2, 14, and 23 days, respectively, after he lost contact with them in the delta. During weeks when we searched from the

Table 2. Frequency distribution of distances traveled by Double-crested Cormorants (Phalacrocorax auritus) between night roost and day locations from 5 January through 26 March 1997 in the delta region of Mississippi.

\begin{tabular}{|c|c|c|c|c|c|c|c|c|c|c|c|}
\hline \multirow[b]{2}{*}{ Comparison } & \multicolumn{10}{|c|}{ Distance $(\mathrm{km})$} & \multirow[b]{2}{*}{$\mathrm{N}$} \\
\hline & $0-10$ & $11-20$ & $21-30$ & $31-40$ & $41-50$ & $51-60$ & $61-70$ & $71-80$ & $81-90$ & $91-100$ & \\
\hline \multicolumn{12}{|c|}{ Night roost to subsequent day location } \\
\hline Males & 23 & 23 & 39 & 9 & 4 & 1 & 2 & 1 & 1 & 1 & 104 \\
\hline Females & 2 & 4 & 7 & 3 & 3 & 0 & 0 & 0 & 0 & 1 & 20 \\
\hline \multicolumn{12}{|c|}{ Night roost to subsequent day location } \\
\hline Harassed & 2 & 4 & 4 & 2 & 2 & 1 & 1 & 2 & 0 & 1 & 19 \\
\hline Not harassed & 13 & 11 & 22 & 6 & 1 & 1 & 0 & 0 & 0 & 0 & 54 \\
\hline \multicolumn{12}{|c|}{ Night roost to subsequent night roost(s) } \\
\hline Harassed & 2 & 3 & 2 & 0 & 1 & 0 & 0 & 0 & 0 & 0 & 8 \\
\hline Not harassed & 44 & 9 & 16 & 3 & 2 & 2 & 0 & 0 & 0 & 0 & 76 \\
\hline
\end{tabular}




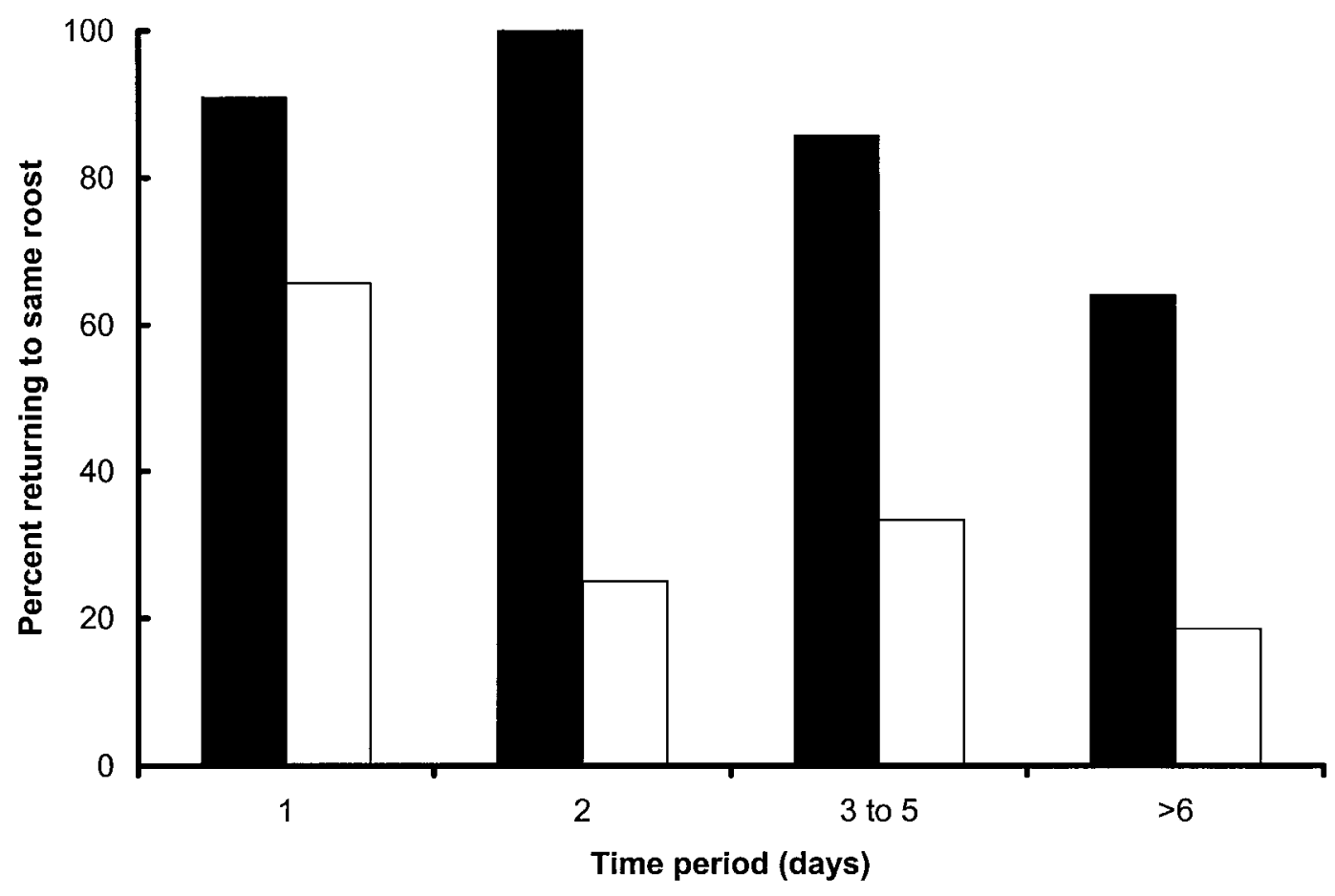

Figure 2. Percentage of Double-crested Cormorants that returned to the same night roosting site from 1 to over 6 nights after first being located in the western (not harassed; black bars) and eastern (harassed; white bars) portions of the delta region of Mississippi.

ground and the air, we located $54-69 \%$ of the radio-telemetered birds. Many that we did not locate during single tracking sessions may have left the delta and flown to the Gulf coast or across the Mississippi River to Arkansas.

Overall, day locations and night roost locations of females were divided approximately evenly between the eastern and western portions of the delta. In contrast, males were primarily located (day and night) in the eastern delta. Glahn et al. (1995) also reported skewed sex ratios of cormorants in the eastern and western delta, which they related to differences in the proportion of the diet consisting of catfish $(60 \%$ for males and $22 \%$ for females). More study is needed to clarify sexual differences in utilization of catfish farms and to explore implications for controlling predation.

Individual cormorants in the delta tended to frequent the same roosts throughout the late winter and early spring. Birds in our study used an average of 2.3 roosts during an average of 30.2 days that we monitored their movements. Similarly, King (1996) reported an average of 2.1 roosts used by each cormorant during late winter. The largest percentage of birds that we followed $(38 \%)$ used only one night roost, and only $18 \%$ used more than three roosts. King (1996) reported that $28 \%$ of the birds he observed used only one roost, and only $4 \%$ used more than three roosts.

Cormorants in our study foraged relatively close to their night roosts. Only $11 \%$ of the birds that we observed roosting in the western delta traveled to the eastern delta to forage the following day. King et al. (1995) followed individual cormorants as they left their roosts in the morning and reported a mean distance of $15.7 \mathrm{~km}$ from the roost to where they first foraged. Our slightly greater median distance of $>20 \mathrm{~km}$ between night roosts and day locations may have been increased because our day locations were not necessarily where the birds stopped first. Although potentially influenced by our small sample size for females $(\mathrm{N}=20)$, females 
were observed to travel a greater distance than males from night roosts to subsequent foraging locations.

Birds roosting along the Mississippi River did not use catfish farms in the eastern portion of the delta during the time that we followed their movements. Most birds remained in one general area during this period. Locations for 15 of the birds that we followed were restricted to the eastern delta, and for eleven birds were restricted to the western delta; we observed only 13 cormorants in both areas.

Our study confirms the contention of Mott et al. (1998) that pyrotechnic and noisemaking devices can be effective in dispersing cormorants from night roosts. However during our study, the roost harassment program did not result in reduced use of night roosts in the eastern delta or less foraging during the day at catfish farms in the eastern delta. When harassed, cormorants did not vacate the eastern delta, but only moved to alternative nonharassed sites and continued to forage on catfish farms in the eastern delta. King (1996) observed a similar phenomenon, which he attributed to asynchronous harassment of birds in different roosts. Harassment during our study was also sporadic and asynchronous except during the last week of March, when many of the birds had already migrated north and the study was nearly completed. During our study, harassers visited each roost an average of only 4.6 times, mostly during the last week of March. In contrast, Mott et al. (1998) harassed all known active roosts in the eastern delta an average of 22 and 35 times, respectively, during two consecutive years.

\section{Management Implications}

Dispersing cormorants out of the eastern region of the delta requires frequent and simultaneous harassment of birds at all active roosts throughout the eastern delta. This is a logistic challenge that requires the coordinated efforts of multiple teams of people throughout an extensive region. Coordinated dispersal efforts have been made more difficult given the continued increase in cormorant roost sites in the delta from 18 in 1989-1991 (Aderman and Hill 1995) to over
80 in 1997 (G. Ellis, unpubl. data). Moreover, the abundance of cormorants in this region during winter has increased from an average of about 30,000 birds between 1989 and 1993 (Glahn et al. 1996) to over 64,000 birds since the winter of 1997-98 (Glahn et al. 2000).

Cormorants cause considerable economic losses to the Mississippi catfish industry (Glahn et al. in press), and a cormorant roost dispersal program can be an effective, nonlethal component of an integrated approach to reducing these impacts. Since cormorants in our study foraged relatively close to their night roosts and only $11 \%$ of the birds that we observed roosting in the western delta traveled to the eastern delta to forage the following day, coordinated dispersal of cormorants from the interior delta may temporarily limit cormorant impacts to catfish production (Mott et al. 1998). The success of future roost harassment programs will not only depend on intensive and synchronous dispersal efforts, but also the ability of such programs to accommodate increasing numbers of cormorants and their roost sites.

\section{ACKNOWLEDGMENTS}

J. B. Harrel helped capture and process cormorants. B. Nygren piloted the airplane and helped locate birds. R.E. Engeman and J. A. Shivik advised on the statistical analyses. M. L. Avery, L. Clark, C. Frank, and J. F. Glahn reviewed an earlier draft of this manuscript.

\section{LITERATURE CITED}

Aderman, A. R. and E. P. Hill. 1995. Locations and numbers of Double-crested Cormorants using winter roosts in the delta region of Mississippi. Colonial Waterbirds 18 (Special Publication 1): 143-151.

Belant, J. L., L. A. Tyson and P. M. Mastrangelo. 2000. Effects of lethal control at aquaculture facilities on populations of piscivorous birds. Wildlife Society Bulletin 28: 379-384.

Buckley, P. A. and F. G. Buckley. 1984. Expanding Double-crested Cormorant and laughing gull populations on Long Island, NY. Kingbird 34: 47-155.

Casaux, R., M. Favero. P. Silva and A. Baroni. 2001. Sex differences in diving depths and diet of Antarctic shags at the south Shetland Islands. Journal of Field Ornithology 72: 22-29.

Catfish Institute. 1998. Reel in the facts about genuine U.S. farm-raised catfish (March 24).

Dunstan, T. C. 1972. A harness for radio-tagging raptorial birds. Inland Bird Banding News 44: 4-8.

Glahn, J. F. and K. E. Brugger. 1995. The impact of Double-crested Cormorants on the Mississippi Delta catfish industry: a bioenergetics model. Colonial Waterbirds 18 (Special Publication 1): 168-175. 
Glahn, J. F., P. J. Dixon, G. A. Littauer and R. B. McCoy. 1995. Food habits of Double-crested Cormorants wintering in the delta region of Mississippi. Colonial Waterbirds 18 (Special Publication 1): 158-167.

Glahn, J. F., A. May, K. Bruce, and D. Reinhold. 1996. Censusing Double-crested Cormorants (Phalacrocorax auritus) at their winter roosts in the delta region of Mississippi. Colonial Waterbirds 19: 73-81.

Glahn, J. F. and R. B. McCoy. 1995. Measurements of wintering Double-crested Cormorants and discriminant models of sex. Journal of Field Ornithology 66 : 299-304.

Glahn, J. F., D. S. Reinhold and C. A. Sloan. 2000. Recent population trends of Double-crested Cormorants wintering in the delta region of Mississippi: responses to roost dispersal and removal under a recent depredation order. Waterbirds 23: 8-44.

Glahn, J. F. and A. R. Stickley, Jr. 1995. Wintering Double-crested Cormorants in the delta region of Mississippi: population levels and their impact on the catfish industry. Colonial Waterbirds 18 (Special Publication 1): 137-142.

Glahn, J. F., M. E. Tobin and J. B. Harrel. 1999. Possible effects of catfish exploitation on overwinter body condition of Double-crested Cormorants. Pages 107114 In M. E. Tobin, Technical Coordinator. Symposium on Double-crested Cormorants: population status and management issues in the Midwest (December 9, 1997, Milwaukee, WI). Tech. Bull. 1879. Washington, D.C.: U.S. Department of Agriculture, Animal and Plant Health Inspection Service.

Glahn, J. F., S. J. Werner, T. Hanson and C. R. Engle. In Press. Cormorant depredation losses and their prevention at catfish farms: economic considerations. Proceedings of Human Conflicts with Wildlife: Economic Considerations Conference.

Hatch, J. J. 1984. Rapid increase of Double-crested Cormorants nesting in southern New England. American Birds 38: 984-988.

Hatch, J. J. 1995. Changing populations of Double-crested Cormorants. Colonial Waterbirds 18 (Special Publication 1): 8-24.

Hatch, J. J. and D. V. Weseloh. 1999. Double-crested Cormorant (Phalacrocorax auritus). In The Birds of North America, No. 441 (A. Poole and F. Gill, Eds.). The Birds of North America, Inc., Philadelphia.

Hess, K. D. 1994. Effectiveness of shooting Double-crested Cormorants on catfish ponds and harassment of roosts to protect farm-raised catfish. Unpublished M.S. thesis, Mississippi State University.

King, D. T. 1996. Movements of Double-crested Cormorants among winter roosts in the delta region of Mississippi. Journal of Field Ornithology 67: 205-211.

King, D. T., K. J. Andrews, J. O. King, R. D. Flint and J. F. Glahn. 1994. A night-lighting technique for capturing cormorants. Journal of Field Ornithology 65: 254-257.

King, D. T., J. F. Glahn and K. J. Andrews. 1995. Daily activity budgets and movements of winter roosting Double-crested Cormorants determined by biotelemetry in the delta region of Mississippi. Colonial Waterbirds 18 (Special Publication 1): 152-157.
Krohn, W. B., R. B. Allen, J. R. Moring and A. E. Hutchinson. 1995. Double-crested Cormorants in New England: population and management histories. Colonial Waterbirds 18 (Special Publication 1): 99-109.

Ludwig, J. P. 1984. Decline, resurgence and population dynamics of Michigan and Great Lakes Doublecrested Cormorants. Jack-Pine Warbler 62: 90-102.

Mott, D. F., K. J. Andrews and G. A. Littauer. 1992. An evaluation of roost dispersal for reducing cormorant activity on catfish ponds. Proceedings of the Eastern Wildlife Damage Conference 5: 205-211.

Mott, D. F. and F. L. Boyd. 1995. A review of techniques for preventing cormorant depredations at aquaculture facilities in the southeastern United States. Colonial Waterbirds 18 (Special Publication 1): 176180 .

Mott, D. F. and M. W. Brunson. 1997. A historic perspective of catfish production in the Southeast in relation to avian predation. Proceedings of the Eastern Wildlife Damage Conference 7: 3-30.

Mott, D. F., J. F. Glahn, P. L. Smith, D. S. Reinhold, K. J. Bruce and C. A. Sloan. 1998. An evaluation of dispersing Double-crested Cormorants from winter roosts for reducing predation on catfish in Mississippi. Wildlife Society Bulletin 26: 584-591.

Reinhold, D. S., A. J. Mueller, and G. Ellis. 1998. Observations of nesting Double-crested Cormorants in the delta region of Mississippi. Colonial Waterbirds 21: 466-467.

Reinhold, D. S. and C. A. (Bo) Sloan. 1999. Strategies to reduce Double-crested Cormorant depredation at aquaculture facilities in Mississippi. Pages 99-105 In M. E. Tobin, Technical Coordinator. Symposium on Double-crested Cormorants: population status and management issues in the Midwest (December 9, 1997, Milwaukee, WI). Tech. Bull. 1879. Washington, D.C.: U.S. Department of Agriculture, Animal and Plant Health Inspection Service.

SAS Institute, Inc. 1989a. SAS/STAT user's guide, version 6 , fourth edition, volume 1 . SAS Institute Inc., Cary.

SAS Institute, Inc. 1989b. SAS/STAT user's guide, version 6 , fourth edition, volume 2 . SAS Institute Inc., Cary.

Tyson, L. A., J. L. Belant, F. J. Cuthbert and D. V. (Chip) Weseloh. 1999. Nesting populations of Double-crested Cormorants in the United States and Canada. Pages 17-26 In M. E. Tobin, Technical Coordinator. Symposium on Double-crested Cormorants: population status and management issues in the Midwest (December 9, 1997, Milwaukee, WI). Tech. Bull. 1879. Washington, D.C.: U.S. Department of Agriculture, Animal and Plant Health Inspection Service.

Weseloh, D. V., P. J. Ewins, J. Struger, P. Mineau, C. A. Bishop, S. Postupalsky and J. P. Ludwig. 1995. Double-crested Cormorants of the Great Lakes: changes in population size, breeding distribution and reproductive output between 1913 and 1991. Colonial Waterbirds 18 (Special Publication 1): 48-59.

Wtanuki, Y., A. Kato and Y. Naito. 1996. Diving performance of male and female Japanese cormorants. Canadian Journal of Zoology 74: 1098-1109. 